Arkadiusz Rzepkowski

(Uniwersytet Łódzki

Wydział Filozoficzno-Historyczny

Katedra Historii Historiografii i Nauk Pomocniczych Historii)

\title{
POZIOM WYKSZTALCENIA LUDNOŚCI WOJEWÓDZTWA ŁÓDZKIEGO W II RZECZYPOSPOLITEJ
}

$\mathrm{P}$ oziom wykształcenia ludności jest podstawą nowoczesnego rozwoju społeczeństwa. W dotychczasowych badaniach dotyczących tej kwestii koncentrowano się przede wszystkim na całej ludności Drugiej Rzeczypospolitej ${ }^{1}$. Zachodzi jednak potrzeba przeprowadzenia takich badań w odniesieniu do populacji poszczególnych województw. Niniejszy artykuł poświęcony jest poziomowi wykształcenia ludności województwa łódzkiego, które miało charakter rolniczo-przemysłowy, $\mathrm{z}$ największym ośrodkiem industrialnym kraju, jakim była Łódź. Bazę źródłową tej pracy stanowią wyniki powszechnych spisów ludności dokonanych w okresie międzywojennym.

Pierwszy powszechny spis ludności z $1921 \mathrm{r}$. dostarczył informacji o rodzaju wykształcenia ludności województwa łódzkiego, zarówno w odniesieniu do całej jego populacji, ludności miejskiej oraz ludności wiejskiej. Badaną społeczność podzielono na kategorie wg następujących rodzajów wykształcenia: domowe, początkowe, średnie, zawodowe średnie i niższe, wyższe, niewiadome, nie umiejący czytać (analfabeci), umiejętność czytania niewiadoma².

Wykresy nr 1-3 ukazują rodzaj wykształcenia ludności województwa łódzkiego w wieku 10 lat i więcej ${ }^{3}$. W $1921 \mathrm{r}$. wykształcenie początkowe posiadało 40,05\% tej społeczności. Znaczną część ludności województwa łódzkiego stanowili analfabeci - 30,31\%. Dużą grupą stanowiły osoby posiadające wykształcenie domowe - 14,19\%. Udział mieszkańców z wykształceniem średnim wynosił 3,79\%. Wskaźnik osób z wykształceniem wyższym był znikomy, podobnie

\footnotetext{
${ }^{1}$ Zagadnieniem tym zajmował się A. Gawryszewski. Zob.: A. Gawryszewski, Ludność Polski w XX w., Warszawa 2005, s. 319-335.

${ }^{2}$ Pierwszy powszechny spis Rzeczypospolitej Polskiej z dn. 30 września 1921 roku. Mieszkania. Ludność. Stosunki zawodowe. Województwo łódzkie, „Statystyka Polski”, t. 16, Warszawa 1928, s. 54-65, tabl. VII.

${ }^{3}$ Zdecydowałem się pominąć najmłodszą część społeczeństwa, która wówczas była albo w okresie wczesnego dzieciństwa lub rozpoczynała dopiero edukację.
} 
zresztą jak z wykształceniem zawodowym średnim i niższym. Dość znaczna była grupa ludności o nieustalonym rodzaju wykształcenia $-7,39 \%$.

W miastach poziom wykształcenia był lepszy niż w przypadku ogółu ludności województwa. Udział osób z wykształceniem początkowym był wyższy i wynosił $45,84 \%$, odsetek analfabetów natomiast był niższy aż o 8 punktów procentowych. Odsetek osób z wykształceniem początkowym był na bardzo zbliżonym poziomie w stosunku do ogółu populacji województwa. Wyraźnie większy był udział osób z wykształceniem średnim, który wynosił $8,20 \%$. Wykształcenie wyższe posiadało $0,73 \%$ mieszkańców miast, choć i w tym przypadku wskaźnik ten był nieco większy aniżeli w odniesieniu do całej ludności województwa, podobnie zresztą jak w przypadku osób z wykształceniem zawodowym średnim i niższym.

Zdecydowanie gorzej prezentowało się wykształcenie ludności wiejskiej województwa łódzkiego. Poziom analfabetyzmu na wsi województwa łódzkiego sięgał w tym czasie $30,93 \%$, wykształceniem początkowym mogło się wykazać $38,79 \%$, czyli jednak wyraźnie mniej niż w miastach. Odsetek osób z wykształceniem średnim był bardzo niewielki i wynosił zaledwie $1,01 \%$, a wykształceniem wyższym mogło poszczycić się zaledwie $0,10 \%$ mieszkańców wsi. W stosunku do prawie $10 \%$ mieszkańców wsi w wieku 10 lat i więcej nie udało się ustalić rodzaju wykształcenia.

Wykres 1

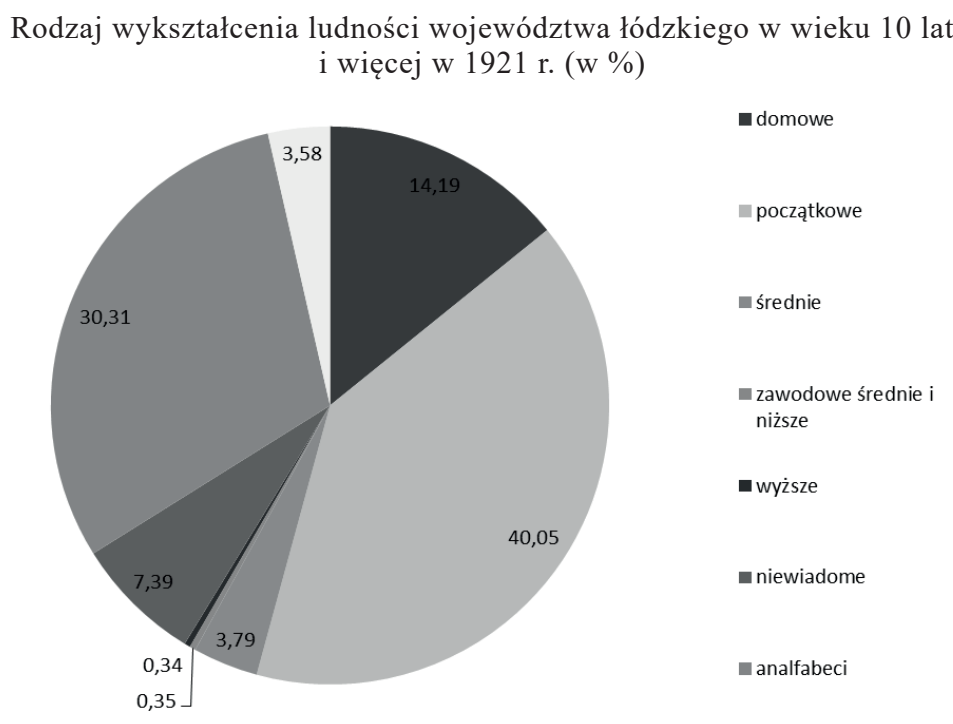

umiejętność czytania niewiadoma

Źródło: Pierwszy powszechny spis Rzeczypospolitej Polskiej z dn. 30 września 1921 roku. Mieszkania. Ludność. Stosunki zawodowe. Województwo łódzkie, „Statystyka Polski”, t. 16, Warszawa 1928, s. 54-55, tabl. VII (obliczenia własne). 
Województwo łódzkie w tym czasie nie odbiegało więc zasadniczo od reszty kraju, a nawet pod względem umiejętności czytania i pisania sytuacja w nim wyglądała nieco lepiej niż w skali całego kraju, w którym to połowa mieszkańców była analfabetami. Analfabetyzm był wyższy na wsi niż w mieście, jedynie w województwach zachodnich - charakteryzujących się najlepszym wykształceniem ludności - wskaźniki analfabetyzmu były zbliżone na wsi i w miastach. Nieco gorzej była wykształcona jednak ludność miejska województwa łódzkiego, w skali całego kraju bowiem 12,6\% mieszkańców miast miało wykształcenie „wyższe” od zawodowego ${ }^{4}$. Stan taki był zapewne wynikiem tego, iż w strukturze społecznej ludności miast województwa łódzkiego - szczególnie tych o charakterze przemysłowym - duży udział mieli robotnicy, którzy byli dość słabo wykształceni.

Wykres 2

Rodzaj wykształcenia ludności miejskiej województwa łódzkiego w wieku 10 lat i więcej w 1921 r. (w \%)
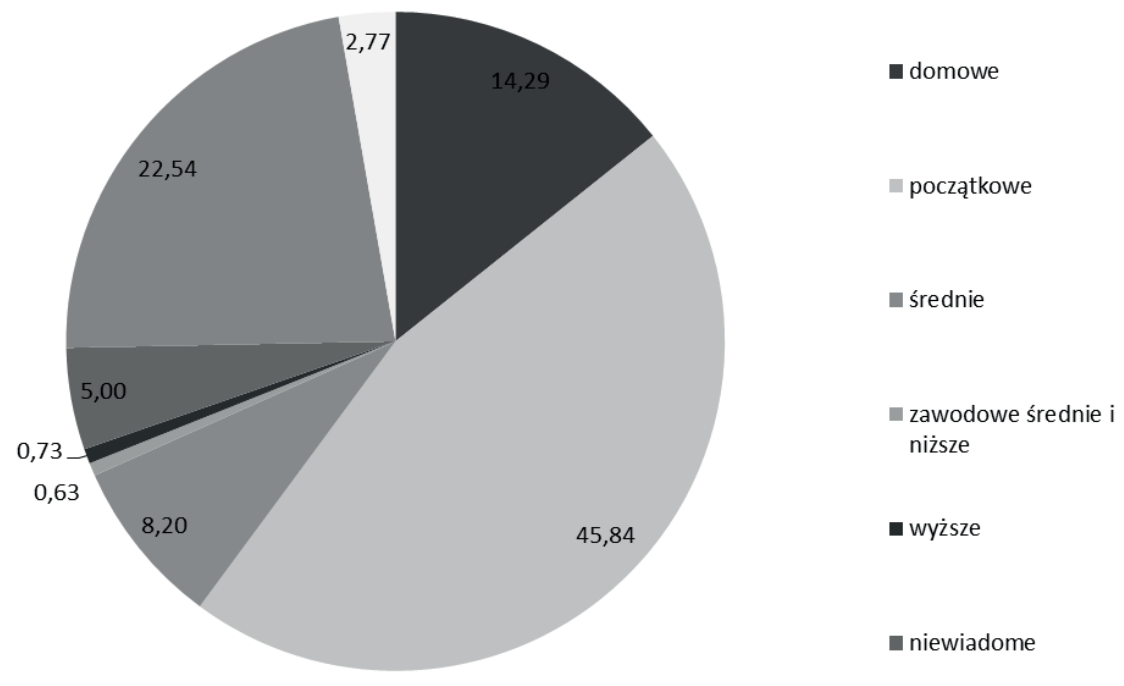

analfabeci

umiejętność czytania niewiadoma

Źródło: Pierwszy powszechny spis Rzeczypospolitej Polskiej z dn. 30 września 1921 roku. Mieszkania. Ludność. Stosunki zawodowe. Województwo tódzkie, „Statystyka Polski”, t. 16, Warszawa 1928, s. 58-59, tabl. VII (obliczenia własne).

\footnotetext{
${ }^{4}$ A. Gawryszewski, Ludność Polski..., s. 320-321.
} 
Rodzaj wykształcenia ludności wiejskiej województwa łódzkiego w wieku 10 lat i więcej w 1921 r. (w \%)

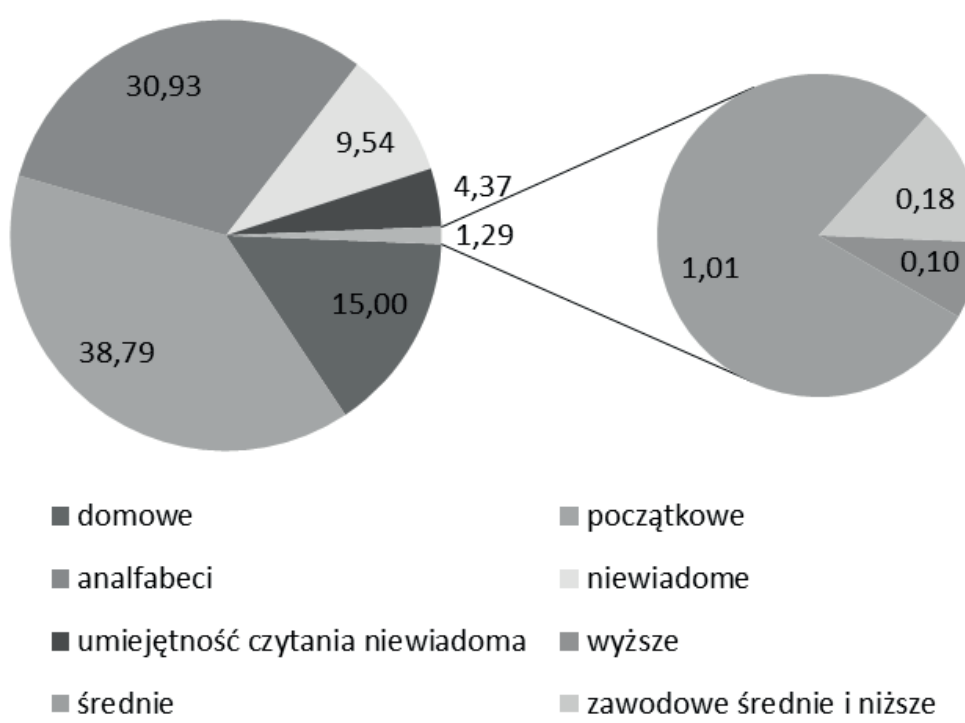

Źródło: Pierwszy powszechny spis Rzeczypospolitej Polskiej z dn. 30 września 1921 roku. Mieszkania. Ludność. Stosunki zawodowe. Województwo łódzkie, „Statystyka Polski”, t. 16, Warszawa 1928, s. 62-63, tabl. VII (obliczenia własne).

Wyniki drugiego powszechnego spisu ludności z 1931 r. zawierają dane dotyczące umiejętności czytania i pisania ludności województwa łódzkiego w wieku 5 lat i więcej w różnych przekrojach, czyli w odniesieniu do ludności całego województwa, ludności miejskiej, mieszkańców miast liczących powyżej 20000 mieszkańców oraz populacji wiejskiej. Dokonano tym razem podziału badanej ludności na następujące kategorie: umiejący czytać i pisać, umiejący tylko czytać, nie umiejący czytać ani pisać oraz osoby w stosunku do których umiejętność czytania i pisania jest niewiadoma ${ }^{5}$. W odróżnieniu więc od wyników pierwszego powszechnego spisu ludności tym razem nie wzięto pod uwagę całej ludności lecz pominięto najmłodszą część mieszkańców województwa.

${ }^{5}$ Drugi powszechny spis ludności z dn. 9.XII.1931 r. Mieszkania i gospodarstwa domowe. Ludność. Stosunki zawodowe. Miasto Łódź, „Statystyka Polski”, Warszawa 1937, seria C, z. 67, s. 24, tabl. 16; Drugi powszechny spis ludności z dn. 9.XII.1931 r. Mieszkania i gospodarstwa domowe. Ludność. Stosunki zawodowe. Województwo łódzkie bez miasta Łodzi, „Statystyka Polski”, Warszawa 1938, seria C, z. 77, s. 54-63, tabl. 16. 
Zdecydowałem się ustalić umiejętność czytania i pisania w odniesieniu do grupy ludności w wieku 10 lat i więcej ${ }^{6}$. Umiejętność tę dla ludności w tym przedziale wieku dla mieszkańców województwa łódzkiego, jego populacji miejskiej, ludności miast powyżej 20000 mieszkańców oraz społeczności wiejskiej przedstawiają wykresy $\mathrm{nr} 4-7$.

Wykres 4

Ludność województwa łódzkiego w wieku 10 lat i więcej oraz w wieku niewiadomym według umiejętności czytania i pisania w 1931 r. (w \%)

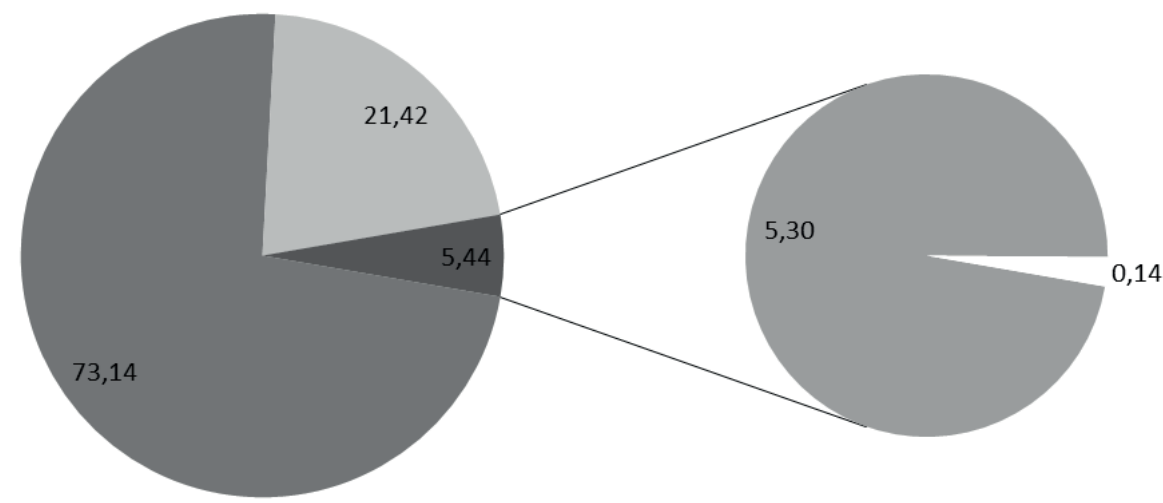

- Umiało czytać i pisać

Umiało tylko czytać
Nie umiało czytać ani pisać

$\square$ Umiejętność czytania i pisania niewiadoma

Źródło: Drugi powszechny spis ludności z dn. 9.XII.1931 r. Mieszkania i gospodarstwa domowe. Ludność. Stosunki zawodowe. Miasto Lódź, „Statystyka Polski”, Warszawa 1937, seria C, z. 67, s. 24, tabl. 16; Drugi powszechny spis ludności z dn. 9.XII.1931 r. Mieszkania i gospodarstwa domowe. Ludność. Stosunki zawodowe. Województwo łódzkie bez miasta Łodzi, „Statystyka Polski”, Warszawa 1938, seria C, z. 77, s. 54, tabl. 16 (obliczenia własne).

W 1931 r. umiejętność czytania i pisania przyswojona była przez zdecydowaną większość mieszkańców - 73,14\%, nie posiadało tych umiejętności 21,42\% ludności, natomiast sama umiejętność czytania była zdobyta przez 5,44\% osób. Lepsza pod względem umiejętności czytania i pisania była sytuacja w miastach, gdzie posiadaniem tej umiejętności legitymowało się ok. 80\% ludności, a wskaźnik analfabetyzmu wynosił 17,25\%, w miastach powyżej 20000 mieszkańców wskaźnik analfabetyzmu był nieco niższy i osiągnął poziom $16,66 \%$. Na wsi

\footnotetext{
${ }^{6}$ Pozwoliło to na porównanie wskaźnika analfabetyzmu w stosunku do $1921 \mathrm{r}$.
} 
sytuacja była gorsza, odsetek umiejących czytać i pisać wynosił $68,08 \%$, a analfabetów było 24,65\%. W porównaniu z $1921 \mathrm{r}$. zaznaczyć trzeba, iż zmniejszył się o prawie 10 punktów procentowych udział analfabetów wśród mieszkańców wsi.

Ludność miejska województwa łódzkiego w wieku 10 lat i więcej oraz w wieku niewiadomym według umiejętności czytania i pisania w 1931 r. (w \%)

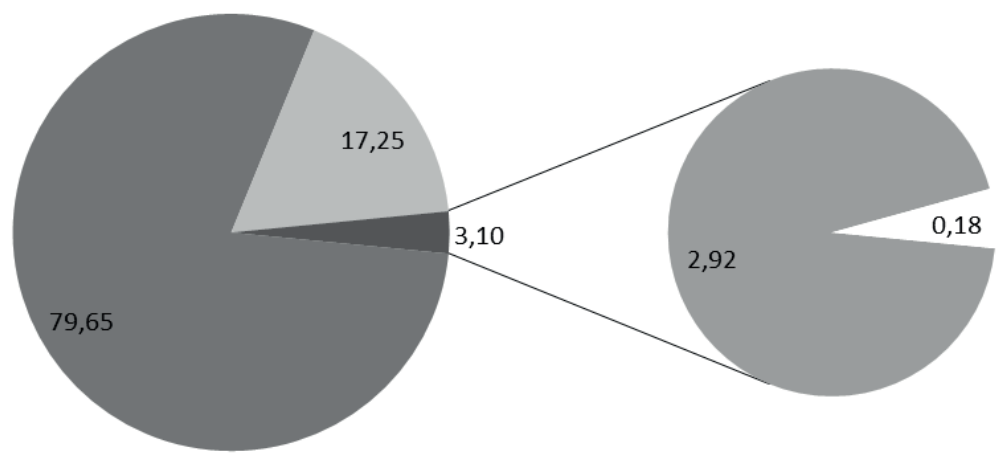

- Umiało czytać i pisać

Nie umiało czytać ani pisać

- Umiało tylko czytać

$\square$ Umiejętność czytania i pisania niewiadoma

Źródło: Drugi powszechny spis ludności z dn. 9.XII.1931 r. Mieszkania i gospodarstwa domowe. Ludność. Stosunki zawodowe. Miasto Łódź, „Statystyka Polski”, Warszawa 1937, seria C, z. 67, s. 24, tabl. 16; Drugi powszechny spis ludności z dn. 9.XII.1931 r. Mieszkania i gospodarstwa domowe. Ludność. Stosunki zawodowe. Województwo łódzkie bez miasta Łodzi, „Statystyka Polski”, Warszawa 1938, seria C, z. 77, s. 56, tabl. 16 (obliczenia własne).

Wysoki odsetek analfabetyzmu na wsi był odziedziczony po epoce zaborów, jak wykazał bowiem powszechny spis ludności przeprowadzony w 1897 r. na terenie Królestwa Polskiego tylko 54\% ludności wiejskiej w grupie wieku między 20 a 29 lat potrafiło czytać i pisać, podczas gdy w miastach wskaźnik dla tego przedziału wieku wynosił $70 \%$.

Wyniki drugiego powszechnego spisu ludności zawierają także dane o umiejętności czytania i pisania w obrębie trzech największych grup wyznaniowych w odniesieniu do ludności w wieku 5 lat i więcej. Największy odsetek umiejących czytać i pisać był wśród mojżeszowych, gdzie dochodził do 80,60\%, dość dobrze pod tym względem wypadali protestanci $-75,88 \%$, dopiero potem usytuowani byli katolicy, wśród których tylko $67,83 \%$ potrafił o czytać i pisać, a analfabetyzm

${ }^{7}$ M. Kopczyński, Wielka transformacja, Warszawa 2006, s. 148. 
Ludność miast województwa łódzkiego liczących powyżej 20000 mieszkańców w wieku 10 lat i więcej oraz $\mathrm{w}$ wieku niewiadomym według umiejętności czytania i pisania w 1931 r. (w \%)

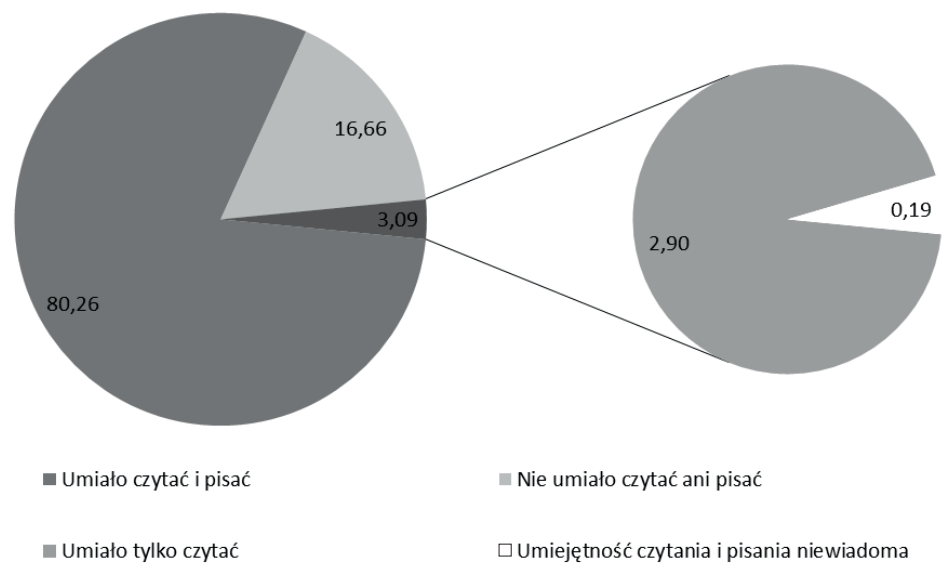

Źródło: Drugi powszechny spis ludności z dn. 9.XII.1931 r. Mieszkania i gospodarstwa domowe. Ludność. Stosunki zawodowe. Miasto Lódź, „Statystyka Polski”, Warszawa 1937, seria C, z. 67, s. 24, tabl. 16; Drugi powszechny spis ludności z dn. 9.XII.1931 r. Mieszkania i gospodarstwa domowe. Ludność. Stosunki zawodowe. Województwo łódzkie bez miasta Łodzi, „Statystyka Polski”, Warszawa 1938, seria C, z. 77, s. 59, tabl. 16 (obliczenia własne).

osiągnął poziom $26,70 \%$. Stan taki był wynikiem tego, iż społeczność mojżeszowa zamieszkiwała przede wszystkim miasta, gdzie poziom wykształcenia był wyższy niż na wsi, w miastach występowała też znaczna większość protestantów. Katolicy z kolei byli społecznością, która w zdecydowanej większości zamieszkiwała wieś województwa łódzkiego.

Wykształcenie ludności województwa łódzkiego w okresie istnienia Drugiej Rzeczypospolitej było charakterystyczne dla województw centralnych, zdecydowanie lepsze od wykształcenia mieszkańców województw wschodnich, lecz gorsze od wykształcenia ludności zamieszkującej województwa zachodnie9. Korzystnym zjawiskiem było stopniowe zmniejszanie się poziomu analfabetyzmu, co niewątpliwie pozytywnie świadczy o rozwoju oświaty na obszarze tego województwa.

${ }^{8}$ Drugi powszechny spis ludności z dn. 9.XII.1931 r. Mieszkania i gospodarstwa domowe. Ludność. Stosunki zawodowe. Miasto Łódź, „Statystyka Polski”, Warszawa 1937, seria C, z. 67, s. 24-25, tabl. 16; Drugi powszechny spis ludności z dn. 9.XII.1931 r. Mieszkania i gospodarstwa domowe. Ludność. Stosunki zawodowe. Województwo łódzkie bez miasta Łodzi, „Statystka Polski”, Warszawa 1938, seria C, z. 77, s. 54-55, tabl. 16. (obliczenia własne)

${ }^{9} \mathrm{~W}$ województwach zachodnich wskaźnik analfabetyzmu był prawie równy zeru. Zob.: A. Gawryszewski, Ludność Polski..., s. 323. 
Ludność wiejska województwa łódzkiego w wieku 10 lat i więcej oraz w wieku niewiadomym według umiejętności czytania i pisania w 1931 r. (w \%)

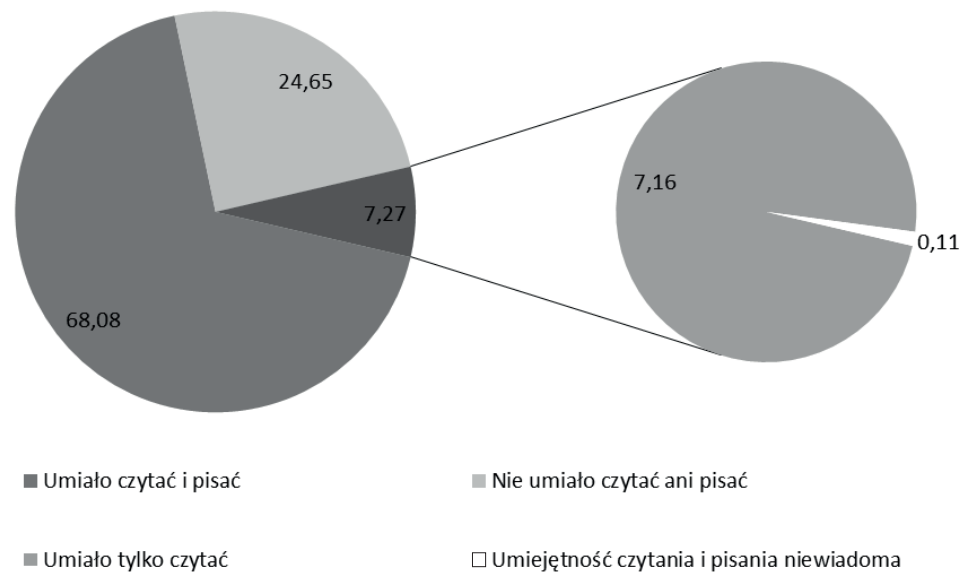

Źródło: Drugi powszechny spis ludności z dn. 9.XII.1931 r. Mieszkania i gospodarstwa domowe. Ludność. Stosunki zawodowe. Województwo tódzkie bez miasta Łodzi, „Statystyka Polski”, Warszawa 1938 , seria $C$, z. 77, s. 61, tabl. 16 (obliczenia własne).

Arkadiusz Rzepkowski

\section{THE LEVEL OF EDUCATION OF PEOPLE IN LÓDŻ VOIEVODSHIP IN THE SECOND POLISH COMMONWEALTH}

The censuses from 1921 and 1931 give information about the level of education in the Łódź province. The census from 1921 gives the data about the education profile of the population, the second one from 1931 about the ability of reading and writing within the population.

At the beginning of the twenties, considering population at the age of ten and older ones, $40.05 \%$ of this community had the primary education. The illiterates made up a large group of $30.31 \%$. $14.19 \%$ made up people who got their education at home. Only $3.79 \%$ of the inhabitants of the province had the secondary education. The index of the people who got higher education and vocational education was low. In 1931 in the group of the above mentioned population $73.14 \%$ possessed the skill of reading and writing, $21.42 \%$ did not possess these skills, $5.44 \%$ of the people could only read.

The education of the Łódź province population was typical of the former Congress Kingdom of Poland terrains during the interwar period. The education was worse comparing to the education from the area of former German annexation yet better than the education of the population coming from Polish eastern frontier. 